\title{
Meeting Wild Bees' Needs on Western US Rangelands
}

\section{By James H. Cane}

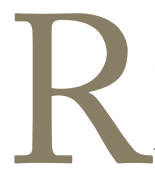

angelands are areas that are too arid, or with soils too shallow, to support either forests or cultivated agriculture, but that nonetheless produce enough vegetation for livestock grazing. Some arid rangeland regions, notably those with warm, dry climates in temperate zones (e.g., the warm deserts of the United States and adjacent Mexico, parts of Australia, South Africa, California, and around the Mediterranean) host great diversities of native bees, ${ }^{1}$ primarily nonsocial species among which are many floral specialists. Conversely, the world's forested lowland tropics support many more social species of bees, but they have far less bee diversity overall. ${ }^{1}$ Bees are generally the most important group of pollinators for every continental flora. To better grasp the relevance of human impacts on rangeland bee faunas, and what we can do about it, some generalizations about bees are presented.

\section{Unfamiliar Bees}

There are about 20,000 described species of bees, with possibly another 10,000 yet to be recognized. ${ }^{1}$ Bees comprise more species than mammals, reptiles, amphibians, and birds combined. The highly social species, such as the true honeybees (Apis) and the stingless bees (Meliponini), have perennial colonies with queens and unmated female workers; they are broad floral generalists found most commonly in the humid tropics. Honeybees are most well known, yet they differ greatly from most other bees. Outside of the tropics, most individuals and species of bees are solitary, each female (of the nonparasitic species) having a central nest that she creates and then provisions for her progeny with individual pellets or masses of pollen moistened with nectar or sometimes floral oils. Most species nest underground (Fig. 1). Others nest aboveground in old beetle tunnels in deadwood or pithy or hollow dead twigs or stems (Fig. 2), or they occasionally make freestanding nests against hard surfaces. Many species have a single 3-5-week adult generation each year. This characteristic is especially prevalent in more arid biomes such as rangelands, where seasonal precipitation often results in a distinct season of bloom and bee activity. An annual life cycle favors some species to evolve taxonomic specialization for pollen, termed oligolecty, which in turn may allow a greater diversity of species to cohabitate. The necessary coordination of bee emergence with bloom seems particularly common in arid, temperate biomes such as rangelands. In summary, the typical rangeland bee is solitary (not social), nests underground, has one generation annually, and is likely, to some degree, to be a floral specialist for pollen. General reading about the fascinating life histories and ecology of bees can be found in Bees of the World, ${ }^{2}$ The Forgotten Pollilnators, ${ }^{3}$ the entry on bees in the Encyclopedia of Entomology, ${ }^{4}$ or at the USDA-ARS Pollinating Insects Lab's Web site. ${ }^{i}$

I will now review some of the human factors with known or expected implications for native bees, with a focus on western rangelands. Missing from this list are climate warming and climate change. In addition, precipitation is a primary factor controlling plant growth and flowering in these arid landscapes, specifically shifting patterns, frequencies, durations and intensities of droughts, as well as various human water-extraction schemes. The timing and amounts of soil moisture strongly impact the rangeland wildflower communities upon which bees depend. However, we cannot yet predict shifts in rangeland precipitation even 1 year in advance, much less any changes in variability under future climates. I therefore prefer to focus on the damage that we know we have done and continue to do to rangelands and on how to implement practical repairs on those landscapes. Most of my recent experience in rangelands comes from the warm deserts and sage-steppe of the western United States, which undoubtedly colors my perspective when extrapolating essentials to rangelands in other parts of the world.

\section{Invasive Exotics}

Rangeland bees are threatened indirectly by those invasive exotic weeds that displace native plant communities. Contrary to some popular notions, bees are not averse to nonnative plants per se. Old World clover and alfalfa crops, for instance, are avidly visited by diverse New World bees, ${ }^{5}$ as are several other papilionaceous legumes that are more

ihttp://www.ars.usda.gov/Services/Services.htm?modecode=54-28-0500 under "What Are Bees?" at the "Products and Services" tab. 


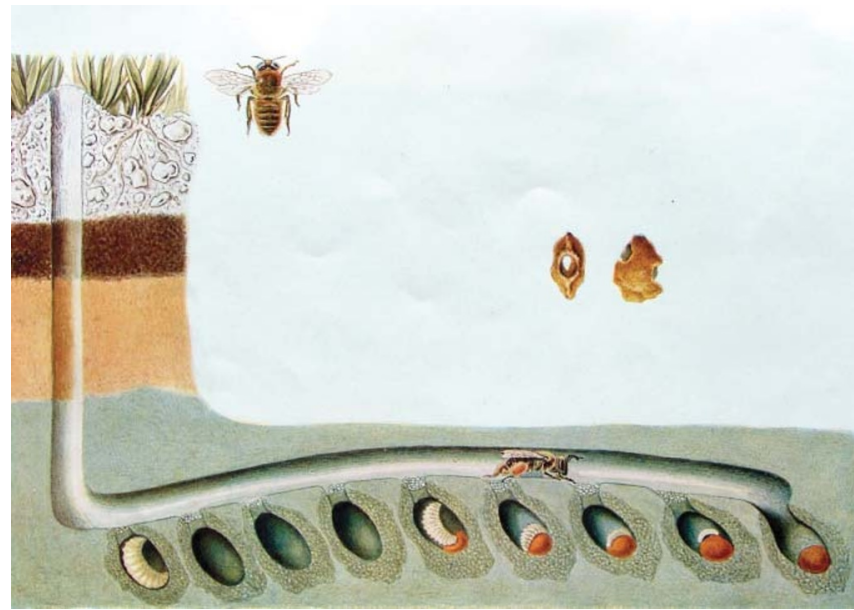

Figure 1. Schematic cross-section illustrating the subterranean nest of the European bee Meliturga clavicornis. Depicted are the main tunnel, mother bee, and her larval progeny at different stages of development on their provision masses of pollen moistened with nectar. From a plate in Die Europaischen Bienen by H. Friese (1923). Reproduced with permission.

invasive in the US West (e.g., yellow sweet clover [Melilotus officinalis] ${ }^{6}$ and sericea [Lespedeza cuneata]). Nonetheless, few of the aggressive exotics infesting rangelands of the American West are useful to native bees. Among the exceptions are saltcedar (Tamarix pentandra), which is abundantly visited by diverse nectar-seeking bees and wasps, and several thistles (e.g., bull thistle [Cirsium vulgare]), which attract bees that visit native thistles. In California, yellow starthistle (Centauria solstitialis) attracts bees too, but mostly exotic species that are also of European origin. ${ }^{7}$ Otherwise, the disruptive exotic weeds of North American rangelands are mostly wind- (or self-) pollinated grasses (e.g., cheatgrass [Bromus tectorum] and buffelgrass [Cenchrus ciliaris]) and forbs (e.g., Russian thistle [Salsola kali]). Most of the exotic forbs of the Great Basin with somewhat more

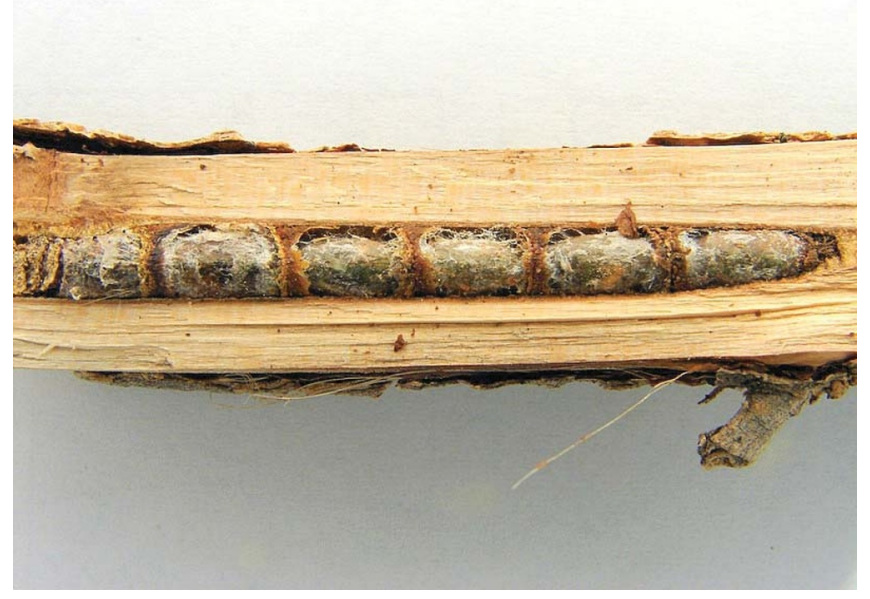

Figure 2. Nest of the solitary bee Osmia kincaidii in a twig of sumac (Rhus trilobata) split open to reveal the linear series of cocoons. Photo by author. showy flowers, such as red storksbill (Erodium cicutarium), tumblemustard (Sisymbrium altissimum), and white top (Cardaria draba), do not seem to attract many native pollinators.

In contrast with livestock, there is no evidence that bees avoid foraging at these exotics because their rewards are unpalatable or toxic. Their threat to bees is entirely due to their capacity to degrade and displace native forb communities (see Rangelands special issue, February 2010) by enhancing fire frequencies ${ }^{8}$ or by poisoning soils through allelopathy ${ }^{9}$ among other mechanisms. After exotic weeds thickly infest disturbed sites, they can impede natural plant recolonization as well as rehabilitation efforts, thereby impeding the restoration of native bee communities. Notably, the 20+ exotic species of bees in North America have produced little detectable disruption of native bee communities thus far, certainly not on a par with exotic plants..$^{10}$ The European honeybee's impact on native bees-mostly through exploitative competition for pollen and nectar-remains debatable and may prove unknowable because they were introduced four centuries ago, long before anyone studied our native bees. In my opinion, it is the precise and targeted elimination of the worst exotic plants-particularly by wellconceived biological control methods-that will eventually benefit native bees the most, if removing the exotic weedy species helps to heal native plant communities.

\section{Pesticides and Rangeland Pollinators}

Pollinators in extensive rangelands are unlikely to encounter toxic insecticides. In contrast, insecticide poisoning is a substantial risk for bees venturing into conventional cropland and orchards, as well as too many suburban landscapes. In sprawling rangeland landscapes, insecticide use is rarely economical or warranted, which is fortunate for bees. One exception in the Intermountain West involves treating outbreaks of grasshoppers and Mormon crickets with bran bait laced with carbaryl insecticide. Bees typically do not contact, collect, or ingest such baits, and even if they do, bees and their progeny are reportedly unharmed. ${ }^{11}$ Herbicides are more widely used on rangelands, but because they do not kill bees, their impact is manifested through their effect on native wildflower communities. This could be beneficial if an aggressive exotic species is selectively removed, or it could be detrimental if all forbs are removed to promote grass monocultures. In general, bees of rangelands are at little direct risk from pesticide exposure, except where rangelands abut more intensive land uses (e.g., cultivated crops or urban sprawl) and their attendant insecticides.

\section{Fire and Bees}

The casual observer gazing at a charred landscape might conclude that fires destroy rangelands. In those parts of the Great Basin and prairie biomes of North America that are without invasive weed problems or altered fire cycles, however, native grasses and forbs generally benefit from 
infrequent fire ${ }^{12,13}$ at the expense of woody plants, such as junipers (Juniperus) and sagebrush (Artemesia), which die when burned. What then of bees? Obviously, those bee species nesting in twigs and stems (Fig. 2) are swiftly killed by the flames. However, $85 \%$ of bee species in the eastern United States nest underground (no estimates are available for other locations). ${ }^{10}$ Their ground-nesting habit (Fig. 1) generally leaves them unharmed by rangeland fires because conduction of a fire's surface heat into mineral soils is sharply curtailed with depth. ${ }^{14}$ Recent experiments in my lab with heated, damp sand showed that bees of every life stage generally survived temperatures up to $50^{\circ} \mathrm{C}$. Such lethal heat from fire penetrates no more than $5-10 \mathrm{~cm}$ below the surface in the absence of thick combustible surface duffs, ${ }^{15}$ which bees typically avoid for nesting. Jack Neff and I have found that only $9 \%$ of 460 bee species with reported nest depths dig such shallow nests. Consequently, most bees should survive the heat of typical rangeland fires (Fig. 3). This prediction is borne out by ongoing postfire bee surveys in the Great Basin by my student, Byron Love. Where native floras were largely intact before burning, native bee faunas as much as $9 \mathrm{~km}$ beyond the edges of huge wildfires remain diverse and abundant in the months, years and decades after burning. For these rangeland bee faunas, fire is inconsequential, except for its influences on the wildflower communities upon which bees depend.

\section{Tillage and Sprawl}

Irreversible habitat losses do result from urban areas sprawling into rangelands, as does land-use conversion into irrigated farmlands. Where other development (e.g., intense fossil fuel extraction or mining) disrupts rangeland plant communities, their bee faunas undoubtedly suffer, but how much and how permanently is not known. Nearly all of California's Central Valley $\left(55,000 \mathrm{~km}^{2}\right)$ was transformed by cultivated agriculture, aided by altered hydrology and

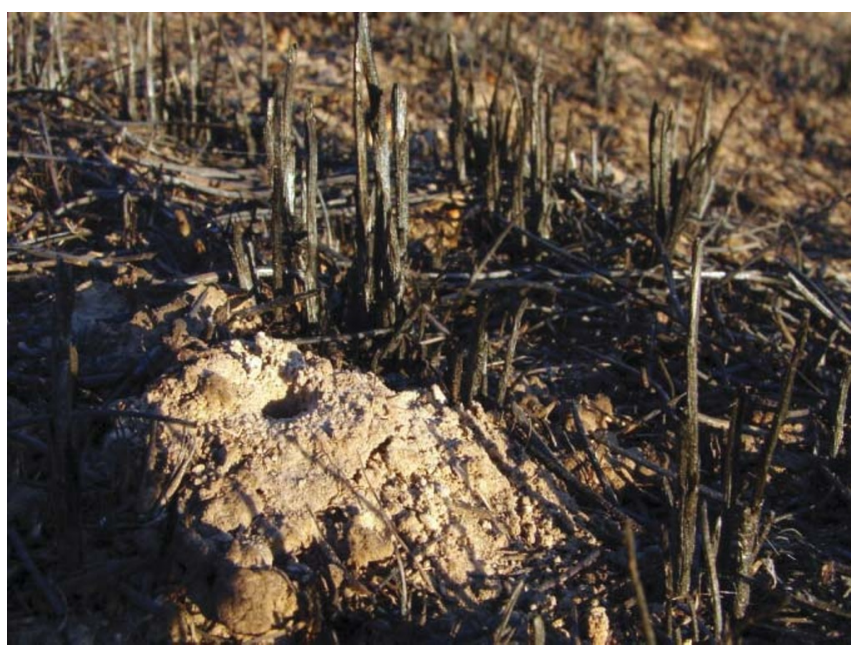

Figure 3. Nest entrance and soil tumulus of the bee Andrena subtilis in the season following a grass fire in sage-steppe. Photo by author. domination by exotic Eurasian annual grasses. John Muir's description of bloom in the former perennial bunchgrass ecosystems is exuberant: "The Great Central Plain of California, during the months of March, April, and May, was one smooth, continuous bed of honey bloom, so marvelously rich that, in walking from one end of it to the other, a distance of more than 400 miles, your foot would press about a hundred flowers at every step" (p. 338). ${ }^{16}$ Muir's enthusiastic hyperbole about bloom intimates that a rich, native bee community must once have existed in California's Central Valley, but no bee biologist was there to collect at that time. Today, that native bee fauna is generally sparse, depauperate, and composed mostly of floral generalists (see Chaplin-Kramer et al., this issue).

Much of the tall- and mid-grass prairies of the central US Great Plains states were plowed to grow annual grain crops that, with few exceptions (e.g., sunflower), do not feed bees. For instance, only $0.1 \%$ of Iowa's original prairies remain. ${ }^{17}$ In the rural environs of Carlinville in southern Illinois, a rich native bee fauna has persisted largely intact from the early 20th century into the 1970 s. ${ }^{18}$ Its subsequent fate with regard to further agricultural intensification, including hedgerow removal and stream-course engineering, is unknown.

More recently, center-pivot irrigation has allowed agricultural intensification to expand westward into more arid rangelands; 8 million hectares in the United States are currently irrigated by center-pivot methods, though not all of it in the West. When aquifers run dry or soils become overly salinated from such arid land irrigation, as can often be inevitable, these farmlands are abandoned. Their churned salty soils, boosted nitrogen loads, and abundance of Eurasian weeds do not favor the return of diverse native plant communities (although desirable forbs can be seeded in the corners left by circles). Even in old crested wheatgrass seedings, however, our collections in northwest Utah and adjacent Idaho have revealed a small lingering subset of the common floral generalists.

Subsets of native bee faunas are surprisingly resilient amid urban sprawl all around the world. ${ }^{19}$ A similar rangeland example is illustrated by the remarkably rich bee fauna at creosote bushes (Larrea tridentata) growing in the alleys and vacant lots of Tucson, Arizona, ${ }^{20}$ a city of the Sonoran desert. These encouraging observations do not justify complacency about curbing urban sprawl and tillage of rangelands, but they do provide hope that surprising numbers of native bees are present and ready to respond to rehabilitation efforts that include suitable wildflowers.

\section{Livestock Grazing Past and Present}

How resilient are native bee communities following rangeland abuse? The extent, severity, causes and cures for past rangeland degradation by livestock grazing in the American West were laid out in a 1936 report to Congress, "The Western Range." This well-organized, lucid, and detailed 
620-page account is accessible on the Web. ii Much less familiar is a case of well-documented historical rangeland devastation ${ }^{21}$ that geographically coincides with a thoroughly known regional bee fauna.

The setting is the Chihuahuan desert scrub and semidesert grasslands in southeastern Arizona, centered around the towering Chiricahua Mountains. Before 1870, the region was sparsely populated, first by native peoples and then Spanish settlers. Soon thereafter, cattle and sheep grazing plus hard-rock mining activities and logging exploded onto the landscape. ${ }^{21}$ In less than 50 years, millions of acres of native perennial grassland were denuded by overgrazing, resulting in plant communities now dominated by unpalatable native shrubs and exotic annuals. In 1891, more than 100,000 cattle grazed Cochise County alone, matched by as many or more sheep. Two years of drought ensued, killing one-half to three-quarters of the herds. The cycle repeated several times into the mid-20th century. Perennial streams and springs dried up. Vast swaths of the conifer forests of the Chiricahua Mountains were clear-cut to supply timbers for copper mines, lumber for mining towns, and charcoal for silver smelters. These intensive land uses have subsided substantially in recent decades, although the rangelands are still grazed.

Did many native bee species survive this devastation? For the past 50 years, the Southwest Research Station of the American Museum of Natural History has regularly hosted bee taxonomists, ecologists, and their students, resulting in a comprehensive regional collection. More than 500 species of native bees are known to reside in the Chiricahua Mountains and especially its surrounding valleys (John Ascher, personal communication, December 2010), despite the ecological degradation during the previous 150 years. Admittedly, some of the dominant invading native shrubs produce abundant flowers that attract diverse bee faunas (e.g., creosotebush [Larrea tridentata] hosts $>120$ bee species), ${ }^{22}$ unlike the wind-pollinated dominant shrubs and grasses of some other rangelands such as the Great Basin. The persistence of diverse native bee faunas on such degraded rangelands bodes well for positive outcomes that can come from rangeland restoration projects that include seeding of bee-pollinated forbs. Progressive management practices for livestock and control of exotic weeds will often be needed if these seedings are to flourish.

An ongoing research study is quantifying the response of native bee communities to recent cessation of grazing and farming in a neighboring warm-desert rangeland. Dr. Robert Minckley's study area is set on a former large ranch in the San Bernardino Valley of northeastern Sonora, Mexico, contiguous with the Chiricahua region mentioned above. Grazing was terminated in 2000, after which native bee and floral community responses were compared in permanent plots of warm desert, scrub grassland, field, and riparian

if Available at http://books.google.com. habitats. Control sites had not been grazed since 1979 . In all, 24,000 individual bees were sampled the first year, representing 306 native species, one-third of which were represented by a single specimen (substantial rarity is the common experience with bee faunal studies). As expected, nearly all of the bee species were nonsocial, most nested underground, and many were floral specialists. Riparian zones returning to cottonwood forest after grazing were unfavorable to this fauna. Otherwise, cessation of grazing resulted in more abundant native bees in each habitat, but the list of species remained constant by habitat type. Monitoring has continued for a further 8 years, with ongoing analysis. A rich, if sparser, bee fauna persisted despite chronic disturbance by grazing; during the decade following the cessation of grazing, that fauna has multiplied somewhat, but its composition has, so far, remained much the same.

Historically, severe grazing clearly degraded and altered native plant communities worldwide, including the western United States. Recovery is far from certain when, as in the last example, livestock are merely removed. Glen Canyon in Utah is a US National Recreation Area today, but for many decades, beginning in the mid-19th century, it was heavily grazed by sheep and other livestock. Studies of plant macrofossil remains in packrat middens (Fig. 4) revealed the composition of plant communities of this high-desert rangeland's during the past 965 years. ${ }^{23}$ Its plant communities endured repeated prehistorical stresses such as severe droughts, but it was the episode of severe livestock grazing that markedly transformed the dominant vegetation, with some palatable forbs and shrub species removed or greatly diminished. Despite elimination of sheep grazing, this plant community remains altered, populated by a more spatially homogenous list of unpalatable though still mostly native plant species, most of which are not used by bees. Native bee communities may need more than mere passive stewardship of wildflower communities following an historical episode of severe grazing disturbance.

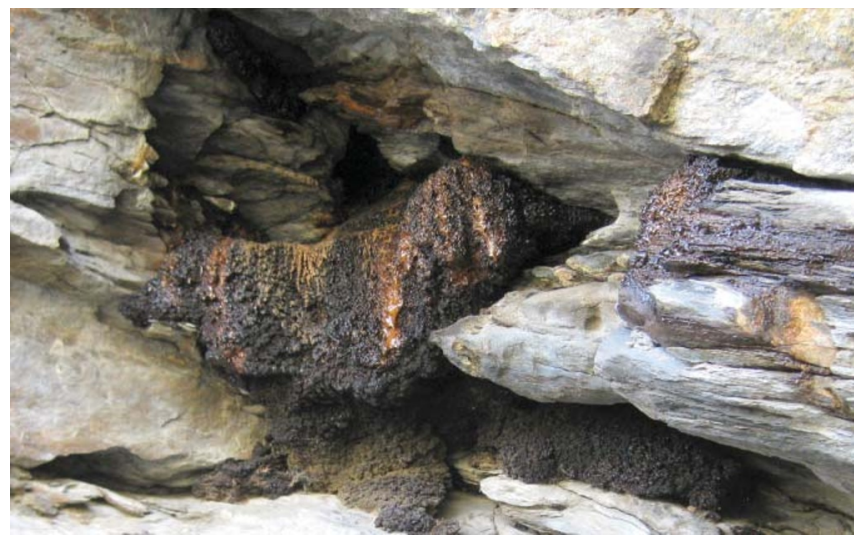

Figure 4. Fossil packrat middens contain preserved fragments and seeds of local vegetation. Photo courtesy of Julio Betancourt, USGS Tucson. 


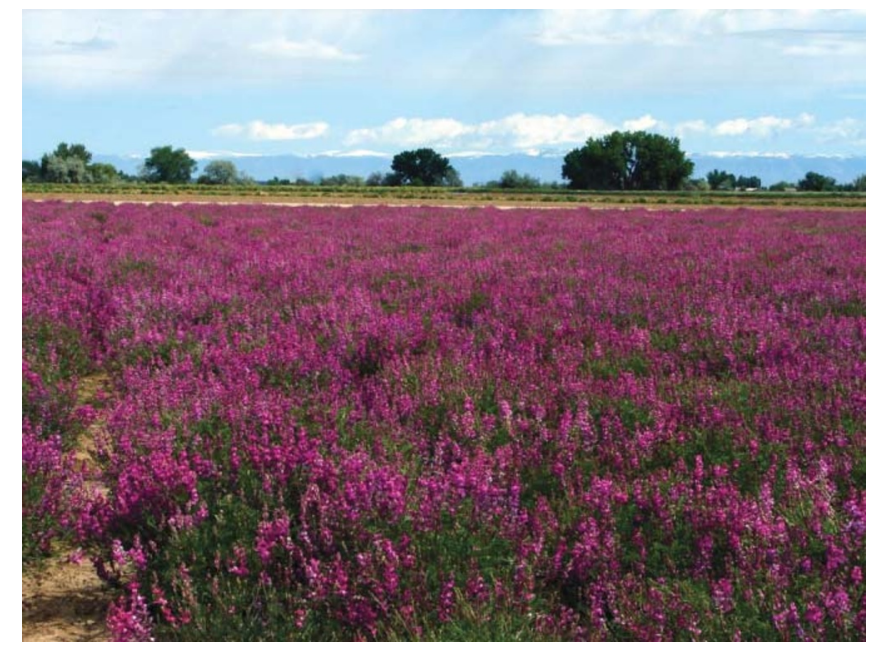

Figure 5. Commercial seed production field for northern sweetvetch (Hedysarum boreale), a perennial herbaceous legume of the Rocky Mountains and eastern Great Basin. Photo by author.

\section{Expanding the Meal Table for Native Bees}

Ultimately, restoring native bee communities to rangeland habitats will, in many places, require or benefit from active restoration of their native plant communities. Specifically, large-scale seeding efforts can be coupled with judicious grazing and fire management. Rocky soils, steep slopes, and harsh climates will limit the number of sites or techniques (e.g., seed drilling vs. aerial seeding) where this approach can be practiced with some hope of success. Restoring rangeland bee communities to presettlement diversity and abundance is not a reasonable objective, both because we lack historical samples of those faunas (and so will remain ignorant of any restoration target) and also because humans caused key ecological transformations that seem irreversible (e.g., degraded cryptobiotic crusts). However, current rangeland bee faunas worldwide would undoubtedly benefit from enhanced diversity and abundance of their native floral hosts. Especially for ground-nesting bees, it seems that carrying capacity in a given habitat is constrained by limited pollen and nectar resources rather than inadequate nesting opportunities. ${ }^{24}$ This is good news because we are progressing in our abilities and capacity to grow and seed wildflowers, but we are generally unsuccessful in creating soil conditions that bees are certain to adopt for nesting. Such plant community rehabilitation by reseeding is increasingly practical and reliable for a growing list of native forbs attractive to native bees.

In North America, especially for the prairies and sagebrush-steppe habitats, a cadre of bold and skilled commercial seed growers is producing seed of diverse native grasses and forbs (Fig. 5). Farmed wildflower seed is cheaper; production is more plentiful and reliable; and the resulting seed is often of better quality than wild-harvested seed-all market factors necessary for widespread adoption and largescale application. The Great Basin wildflowers in line for

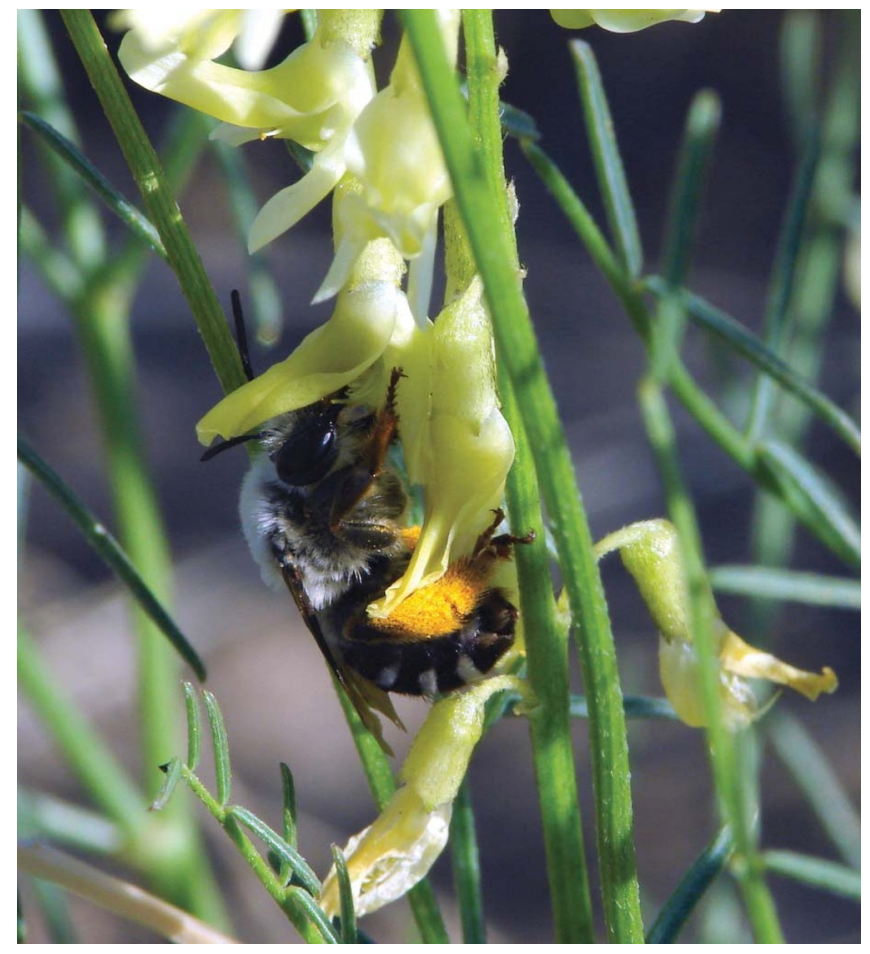

Figure 6. Female of the ground-nesting native bee Eucera frater foraging at flowers of threadstem milkvetch (Astragalus filipes), a host dominated by diverse bees of the genus Osmia. Photo by author.

restoration efforts are all widespread, prevalent species. They represent diverse plant families and happen to be both attractive to native bees (Fig. 6) and are in need of bees' pollination services. ${ }^{25}$ Just one of the species, basalt milkvetch (Astragalus filipes), is unmatched as a host for bees of the genus Osmia (which are prevalent in the Great Basin); we have found fully one-third of all Osmia species of North America visiting its flowers. ${ }^{26}$ In turn, most of the other Great Basin forbs considered for seed production are visited by one or more species of Osmia.

The same can be said for many prevalent prairie forbs useful for restoration in the U.S. Great Plains. For instance, purple prairie-clover (Dalea purpurea) is in commercial seed production on several hundred acres in five states. It both requires bees for seed set (a critical fact for growers) and is used by $50+$ species of native bees for pollen and nectar. ${ }^{27} \mathrm{~A}$ close prairie relative, leadplant (Amorpha canescens), retains a rich bee fauna, including a dominant specialist, even among small prairie remnants. ${ }^{28}$ This additional evidence indicates that relict bee communities are poised to take advantage of nearby revegetation efforts.

Recent advances in seed growing, harvest, cleaning, storage, dormancy management, and especially mechanical seeding technologies are facilitating successful rehabilitation demonstrations on the large acreages needed to convince land managers of their practicality. Research and field trials funded and coordinated through the Great Basin Native Plant Selection and Increase Project through 
the USDI-BLM Great Basin Restoration Initiative and the USDA-FS Rocky Mountain Research Station are at the vanguard of such rehabilitation programs. iii I am convinced that native wildflower restoration is the key to bee community restoration in many rangeland habitats.

\section{Acknowledgments}

I thank Douglas Johnson, Leonard DeBano, and Nancy Shaw for their insights and helpful reviews, Bob Minckley for sharing his exciting research results (now in review), and John Ascher for his expert faunal estimate for the Chiricahua watershed.

\section{References}

1. Michener, C. D. 2007. The bees of the world. Baltimore, MD, USA: Johns Hopkins University Press. 953 p.

2. O’Toole, C., and A. Raw. 1991. Bees of the World. New York, NY, USA: Facts on File, Inc. 192 p.

3. Buchmann, S. L., and G. P. Nabhan. 1996. The forgotten pollinators. Washington, DC, USA: Island Press. 292 p.

4. CAne, J. H. 2008. Bees (Hymenoptera: Apoidea: Apiformes). In: J. L. Capinera [ED.]. Encyclopedia of Entomology. New York, NY, USA: Springer-Verlag Press. p. 419-434.

5. Bohart, G. E. 1957. Pollination of alfalfa and red clover. Annual Review of Entomology 2:355-380.

6. Tepedino, V. J., B. A. Bradley, and T. L. Griswold. 2008. Might flowers of invasive plants increase native bee carrying capacity? Intimations from Capitol Reef National Park, Utah. Natural Areas Journal 28:44-50.

7. Barthell, J. F., J. M. Randall, R. W. Thorp, and A. M. Wenner. 2001. Promotion of seed set in yellow star-thistle by honey bees: Evidence of an invasive mutualism. Ecological Applications 11:1870-1883.

8. МАСК, R. N. 1981. Invasion of Bromus tectorum L. into Western North America: an ecological chronicle. Agro-Ecosystems 7: $145-165$.

9. Bais, H. P., R. Vepachedu, S. Gilroy, R. M. Callaway, and J. M. Vivanco. 2003. Allelopathy and exotic plant invasion: From molecules and genes to species interactions. Science (Washington, D. C.) 301:1377-1380.

10. Cane, J. H. 2003. Exotic non-social bees (Hymenoptera: Apoidea) in North America: Ecological implications. In: K. V. Strickler and J. H. Cane [EDs.]. For non-native crops, whence pollinators of the future? Lanham, MD, USA: Thomas Say Publications in Entomology, Entomological Society of America. p. 113-126.

11. Peach, M. L., D. G. Alston, and V. J. Tepedino. 1995. Sublethal effects of carbaryl bran bait on nesting performance, parental investment, and offspring size and sex ratio of the alfalfa leafcutting bee (Hymenoptera, Megachilidae). Environmental Entomology 24:34-39.

12. Wrobleski, D. W., and J. B. Kauffman. 2003. Initial effects of prescribed fire on morphology, abundance, and phenology of forbs in big sagebrush communities in southeastern Oregon. Restoration Ecology 11:82-90.

iii See http://www.fs.fed.us/rm/boise/research/shrub/greatbasin.shtml.
13. Seefeldt, S. S., M. Germino, and K. Dicristina. 2007. Prescribed fires in Artemisia tridentata ssp. vaseyana steppe have minor and transient effects on vegetation cover and composition. Applied Vegetation Science 10:249-256.

14. Debano, L. F., D. G. Neary, and P. F. Ffolliott. 1998. Fire's effects on ecosystems. New York, NY, USA: John Wiley and Sons. 333 p.

15. Pyne, S. J., P. L. Andrews, and R. D. Laven. 1996. Introduction to wildland fire. New York, NY, USA: John Wiley and Sons. 769 p.

16. Muir, J. 1894. The Mountains of California. New York, NY, USA: The Century Co. $381 \mathrm{p}$.

17. Sмiтн, D. D. 1981. Iowa prairie, an endangered ecosystem. Proceedings of the Iowa Academy of Science 88:7-10.

18. Marlin, J. C., and W. E. Laberge. 2001. The native bee fauna of Carlinville, Illinois, revisited after 75 years: a case for persistence. Conservation Ecology 5:87-89.

19. Cane, J. H. 2005. Bees, pollination, and the challenges of sprawl. In: E. Johnson and M. Klemens [EDs.]. Nature in fragments: the legacy of sprawl. New York, NY, USA: Columbia University Press. p. 109-124.

20. Cane, J. H., R. Minckley, T. Roulston, L. J. Kervin, and N. M. Williams. 2006. Complex responses within a desert bee guild (Hymenoptera: Apiformes) to urban habitat fragmentation. Ecological Applications 16:632-644.

21. Bahre, C. J. 1991. A legacy of change. Tucson, AZ, USA: University of Arizona Press. $231 \mathrm{p}$.

22. Minckley, R. L., J. H. Cane, L. Kervin, and T. H. Roulston. 1999. Spatial predictability and resource specialization of bees (Hymenoptera: Apoidea) at a superabundant, widespread resource. Biological Journal of the Linnean Society, London 67:119-147.

23. Cole, K. L., N. Henderson, and D. S. Shafer. 1997. Holocene vegetation and historic grazing impacts at Capitol Reef National Park reconstructed using packrat middens. Great Basin Naturalist 57:315-326.

24. Roulston, T. H., and K. Goodell. 2010. The role of resources and risks in regulating wild bee populations. Annual Review of Entomology 56:293-312.

25. CANE, J. H. 2008. Pollinating bees crucial to farming wildflower seed for U.S. habitat restoration. In: R. R. James and T. L. PittsSinger [EDs.]. Bees in agricultural ecosystems. New York, NY, USA: Oxford University Press. p. 48-64.

26. Watrous, K. W., and J. H. Cane. 2011. Breeding biology of the threadstalk milkvetch, Astragalus filipes (Fabaceae), with a review of the genus. American Midland Naturalist 165:225-240.

27. Cane, J. H. 2006. An evaluation of pollination mechanisms for purple prairie-clover, Dalea purpurea (Fabaceae: Amorpheae). American Midland Naturalist 156:193-197.

28. Slagle, M. W. and S. D. Hendrix. 2009. Reproduction of Amorpha canescens (Fabaceae) and diversity of its bee community in a fragmented landscape. Oecologia 161:813-823.

Author is Research Entomologist, USDA-ARS Pollinating Insect Research Unit, Utah State University, Logan, Utah 84322-5310, USA, Jim.Cane@ars.usda.gov. Research supported by the Great Basin Native Seed Selection and Increase Project. 